\title{
CURRICULUM DEVELOPMENT MODEL FOR THE LATVIAN LANGUAGE AND LATVIA STUDIES PROGRAM IN CHINA
}

\begin{abstract}
This article discusses the curriculum development model for the Latvian Language and Latvia Studies Program in China. Based on the existing models of language curriculum development, as well as the administrative and pedagogical practice in the Less Commonly Taught European Languages (LCTELS) programs at Beijing Foreign Studies University (BFSU), this article aims to develop a curriculum model specific for the LCTELs programs in China. Document analysis, observation, questionnaire and semi-structured interview are used to reach the set target. This article examines language curricular models, and describes the outcomes of the LCTELs programs practice both in administrative and pedagogical procedures that aim to create a curriculum development model for the Latvian Language and Latvia Studies Program and expectantly, also for other new initial language programs in China's context, in order to get prepared for student enrolment in bachelor's level.
\end{abstract}

Keywords: China's context, language curriculum models, the Latvian Language and Latvia Studies Program.

\author{
ABBREVIATIONS: \\ BFSU - Beijing Foreign Studies University \\ CEFR - Common European Framework of Reference for Languages \\ $\mathrm{EFL}$ - English as a Foreign Language \\ ESL - English as a Second Language \\ LCTELs - Less Commonly Taught European Languages \\ LCTLs - Less Commonly Taught Languages
}




\section{Introduction}

Depth of China-Europe relations is accompanied by the increasing interest and high demand in learning of different European languages, with particular emphasis on Less Commonly Taught European Languages (LCTELs), amongst which Latvian language also takes place.

The Latvian Language and Latvia Studies Program in China (Chinese: 拉脱维亚语专业; hereafter called the Latvian Program) was started in 2010 at Beijing Foreign Studies University (BFSU). So far the program mainly conducts elective courses for non-LCTELs students with the instruction of expatriate teacher from Latvia. However it is planned to recruit the first class of postgraduate students by 2020, when Chinese local teachers accomplish training in Latvia.

The Latvian Program belongs to the group of the LCTELs programs in administration. LCTELs group is a branch of Less Commonly Taught Languages (LCTLs) from a geographical aspect. LCTELs as foreign language teaching in China can be dated back to the 1950s at BFSU with the start of the Polish and Czech language programs. Nowadays BFSU is the main university engaged in the LCTELs programs and offers the widest range of language studies in China, comprising of 20 bachelor programs, 12 master programs, and 4 doctorate programs. The administrative and pedagogical practice of the LCTELs programs at BFSU, primarily at the bachelor level, is the basis of this article.

Curriculum is continuously the central issue in both LCTELs teaching and learning. With the changes in social context, based on environment and need analysis, the LCTELs curriculum has been discussed and improved. Especially since 2000s, the development progress of information and technology field, led to fundamental changes and unprecedented challenges in education. As a result, the curriculum was in frequent revise to meet the evaluation standards and the social demands in the $21^{\text {st }}$ century. In 2007, based on the Common European Framework of Reference for Languages (CEFR), the General Curriculum for Teaching in LCTELs Bachelor Programs was created by a team of LCTELs professors at BFSU. In the same year, BFSU issued the official curriculum of the LCTELs programs, and continuously modifies it every four or five years; this process is guided by latest theories in the field, and classroom and social feedback as well. Coupled with increased national attention - the National Undergraduate Education Evaluation in 2012, the initial of the project "National Quality Standards for Undergraduate Programs" and "Belt and Road" Initiative in 2013, numerous seminars and workshops for LCTELs instructors and curriculum design specialists quest for more effective model to train/teach LCTELs learners. The latest modification for 
the official curriculum of the LCTELs programs at BFSU was completed in 2016. The new curriculum accepted the feedback of graduates, who are now working in different fields; kept the two main parts in previous curriculum, classroom teaching and extracurricular practice; and introduced the "Discipline Directional Module", which is instructed in the target language, in order to prepare students specialised in popular fields.

Although curriculum is being updated, problems still exist: 1) Nowadays curriculum development theories and models are mainly rooted in ESL or EFL teaching and learning in western context, and they cannot be fully adopted for language teaching and learning in China's context; 2) LCTELs curriculum development mainly follows and copies curriculum models of English language program, and it does not fully reflect the features of LCTELs teaching and learning; 3) Most of the LCTELs programs implementers are empiricists, curriculum development theories and models are not fully employed; 4) In the process of curriculum development, attention is mainly paid to pedagogical issues rather than administrational affairs.

Based on the above considerations, this article defines "curriculum" as the total teaching and learning experience either in pedagogical or in administrational aspect, which is planned and guided by the LCTELs programs in China, whether it is carried out in groups or individually, inside or outside the classroom. Through document analyses, four influential language curriculum models are compared to offer a framework for further LCTELs curriculum development. Nation \& Macalister's Model is chosen as basis for this article (comparative analysis shows in Table 1). This model contains a more comprehensive review of factors in curriculum development process than the rest. It is a stratified structure, which shows the overall relations of the different components (see Figure 1). "Principles" are listed as an independent component, to emphasise the importance and guiding role of theories and researches in the developing process, which are easily avoided by the novice practitioners. It distinguishes "assessment" and "evaluation", which refer to measure students learning results and the quality of curriculum respectively. This distinction makes the whole model more concrete and less vague.

Wang (2009) claims that educators and scholars are called to engage in rigorous discussion to develop language specific examples and performance indicators to guide program development and decision making for LCTLs instructors. The main aim of this article is to compare the existing curriculum development models, to adjust the factors based on the practical context in China, and to develop a curriculum framework for the Latvian Program. This framework is a necessary preparation for syllabi and the undergraduate students' enrolment by 2020 . 
Table 1. A comparative analysis of four language curriculum development models (Comparison was developed by the author)

\begin{tabular}{|c|c|c|c|}
\hline $\begin{array}{l}\text { Nation \& } \\
\text { Macalister's } \\
\text { Model (2010) }\end{array}$ & Murdoch's Model (1989) & $\begin{array}{l}\text { Graves' Model } \\
(1996)\end{array}$ & $\begin{array}{l}\text { Richards' } \\
\text { Model (2001) }\end{array}$ \\
\hline $\begin{array}{l}\text { Environment } \\
\text { analysis }\end{array}$ & $\begin{array}{l}\text { Resource limitations that } \\
\text { affect classroom activity; } \\
\text { Socio-cultural factors and } \\
\text { learning habits of relevance } \\
\text { to English teaching; } \\
\text { Aspects of target culture } \\
\text { that will interest learners } \\
\text { and can be exploited in } \\
\text { materials }\end{array}$ & $\begin{array}{l}\text { Consideration } \\
\text { of resources and } \\
\text { constraints }\end{array}$ & $\begin{array}{l}\text { Situation } \\
\text { analysis }\end{array}$ \\
\hline \multirow[b]{2}{*}{ Needs analysis } & $\begin{array}{l}\text { Learners' age group, present } \\
\text { lifestyle and interests }\end{array}$ & \multirow[b]{2}{*}{$\begin{array}{l}\text { Needs } \\
\text { assessment }\end{array}$} & \multirow[b]{2}{*}{ Needs analysis } \\
\hline & $\begin{array}{l}\text { Learners' present level of } \\
\text { competence; } \\
\text { Reasons for studying } \\
\text { English and long-term } \\
\text { learning aims }\end{array}$ & & \\
\hline Principles & - & $\begin{array}{l}\text { Articulating } \\
\text { beliefs (revised } \\
\text { in 2000) }\end{array}$ & - \\
\hline Goals & Course objectives & $\begin{array}{l}\text { Determining } \\
\text { goals and } \\
\text { objectives }\end{array}$ & $\begin{array}{l}\text { Planning goals } \\
\text { and learning } \\
\text { outcomes }\end{array}$ \\
\hline \multirow[b]{2}{*}{$\begin{array}{l}\text { Content and } \\
\text { sequencing }\end{array}$} & \multirow{2}{*}{$\begin{array}{l}\text { Language and procedures to } \\
\text { be covered by the course; } \\
\text { Emphasis on particular } \\
\text { skills; } \\
\text { Themes for course materials } \\
\text { and texts: Choice of suitable } \\
\text { textbooks. }\end{array}$} & $\begin{array}{l}\text { Conceptualizing } \\
\text { content }\end{array}$ & \multirow{2}{*}{$\begin{array}{l}\text { Course planning } \\
\text { and syllabus } \\
\text { design; } \\
\text { Design of } \\
\text { instructional } \\
\text { materials. }\end{array}$} \\
\hline & & $\begin{array}{l}\text { Selecting and } \\
\text { developing } \\
\text { materials and } \\
\text { activities }\end{array}$ & \\
\hline $\begin{array}{l}\text { Format and } \\
\text { presentation }\end{array}$ & $\begin{array}{l}\text { Methodology to be used: } \\
\text { type and sequencing of } \\
\text { activities }\end{array}$ & $\begin{array}{l}\text { Organization } \\
\text { of content and } \\
\text { activities }\end{array}$ & $\begin{array}{l}\text { Providing } \\
\text { for effective } \\
\text { teaching }\end{array}$ \\
\hline $\begin{array}{l}\text { Monitoring and } \\
\text { assessment }\end{array}$ & - & \multirow[t]{2}{*}{ Evaluation } & \multirow{2}{*}{$\begin{array}{l}\text { Approaches to } \\
\text { evaluation }\end{array}$} \\
\hline Evaluation & - & & \\
\hline
\end{tabular}




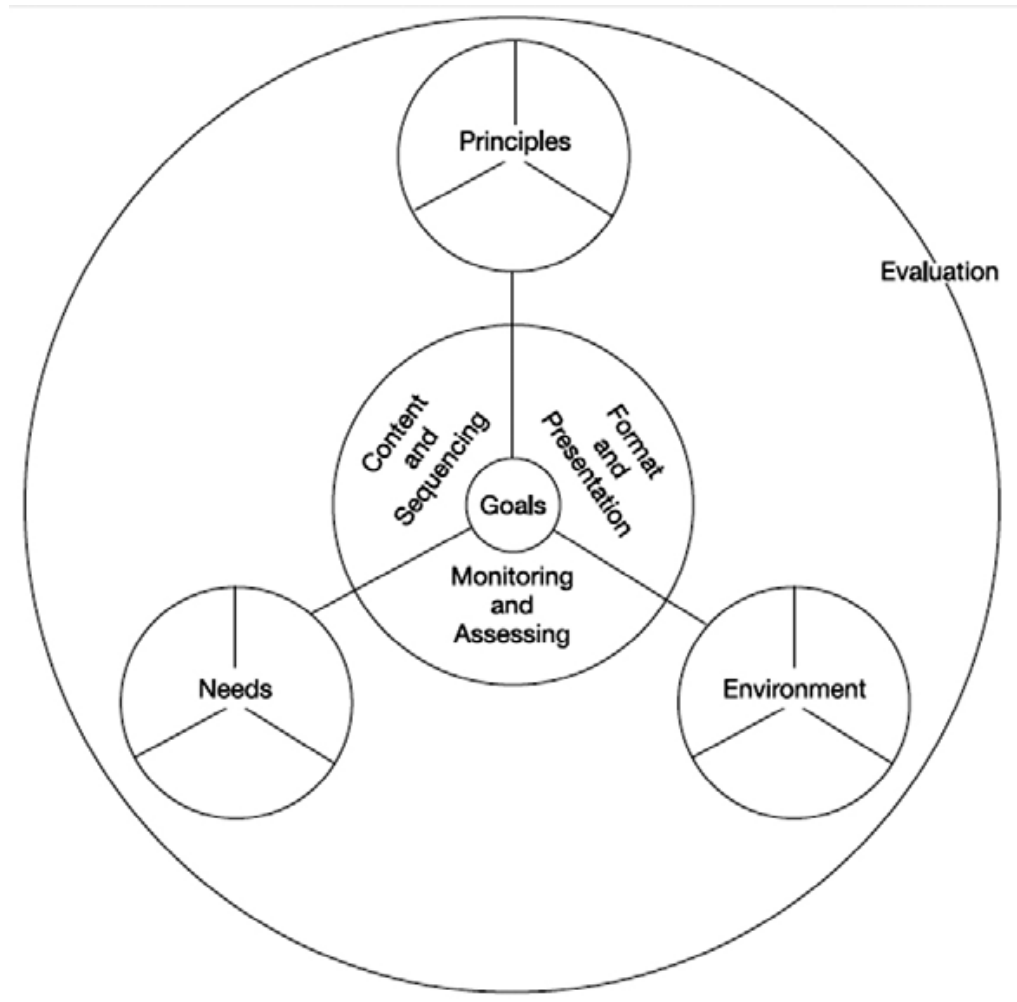

Figure 1. Nation \& Macalister's Model (Nation \& Macalister, 2010)

\section{Methods and Materials}

This article mainly uses the following methods: 1) Document analyses: reviewing the existing language curriculum development models, and the pedagogical/administrative documents in the LCTELs programs. 2) Observation: observing the pedagogical and administrative activities in the LCTELs programs. The full-time administrator of teaching affairs took charge of the whole observation process. Everyday's administrative work was recorded in worksheet. In each semester, 6 lectures in the different LCTELs programs were attended randomly. The observation period is from July, 2012 to December 2017, including 11 semesters. 3) Questionnaire on the theme of "motivation and motivating strategies", which was carried out in January, 2017. Questionnaire employed the Likert Scale with 5 degrees (Strongly agree $\rightarrow$ strongly disagree). Basic information and 36 multiple-choice questions were presented in two parts (Cronbach $\alpha$ were 0.754 and 0.920 respectively). The whole process was organized by e-mail and online questionnaire system, and involved 259 students 
and 31 teachers in 15 LCTELs programs. (Lu, 2018). 4) Semi-structured interviews on the theme of "the brief history of curriculum development in the LCTELs programs" with 51 teachers and administrative staff in the 23 LCTELs programs, which was carried out in July-August, 2017. 5 openended questions were raised to each participant, and snowball method was employed to obtain detailed information.

\section{Results and Discussions}

In this part, particular curriculum development considerations for the LCTELs programs, including the Latvian Program, were discussed in context of China.

\section{Component 1: Environment analysis}

The comprehensive discussion about environment/situation analysis is in Richards' model (Richards, 2001, 90-111); six layers are listed: societal, project, institutional, teacher, learner and adoption factors. For commonly taught languages, especially for English, the theories and researches are rather mature, the materials and resources are abundant, and the communication among different communities is quite frequent, thus societal factors in daily teaching generally are confined to own inner community. However, LCTLs are facing inadequate teacher education programs, the unavailability of pedagogically sound teaching materials and geographical and professional isolation (Brown, 2009; Johnston, Janus, 2003). In order to compensate these disadvantages, factors in wider range - the global context must be analysed. Global factors play a role mainly in two really wide aspects: 1) Target country/region governments and people. Policy and institutions for language promotion, teaching materials and resources, educational organisations, students exchange mechanism, and people's attitude are essential factors for the LCTELs programs; 2) The worldwide teaching situation of LCTELs. Regular communication and cooperation among the LCTELs programs in different countries can share experience and suggestions, and it is an effective way to break geographical isolation.

\section{Component 2: Needs analysis}

When it comes to "needs analysis" in different models, attention is unanimously paid to "learners' needs". This article also explores needs of other main stockholders in practice. 


\section{Learners' needs}

Unlike the direct exploration to learners' needs in the English learning, the analysis in the LCTELs programs is circuitous. Due to geographical distance, students have little knowledge about most of LCTELs and cultures when they enrol in the current programs and hardly express specific needs. Additionally higher education admission system in China cannot guarantee the students enrolled for their first or main interest. LCTELs programs admission requirements, to some extent, are lower than the commonly taught languages programs. If students in the National College Entrance Examination cannot achieve the requirements of the more popular programs, they might be accepted by the LCTELs programs in case if they want. In the questionnaire which was carried out in January, 2017, 62.1\% of respondents answered that the programs they enrolled are not their first choices. But the result does not mean that they are not interested or satisfied in future studies. In the same investigation, $80.5 \%$ and $80.2 \%$ of them showed interests in the target languages and cultures respectively. In the LCTELs programs, to certain degree, to quest the needs of learners is an overlapped process for teachers and administrators to motivate students to find their own needs. As observed, motivating can lead to three results: 1) Fully-motivated. Students are devoted to the LCTEL learning, and decide to pursue professions or further studies related to the language and culture. 2) Partly-motivated. Students can fulfil the assessments in the program, but their expectation of the program is more about completing higher education degree. 3) Non-motivated. Students show no interest in study, and cannot fulfil the assessments in the program.

As three situations may coexist in one program and it makes the curriculum management very complicated, effective administrative process should be considered to lower the contradiction and maximise the concordance. The main measure is to break the barriers between programs/ faculties/universities, to design sub-curriculum, as well as standards for delisting, to offer students more opportunities. The administrative process can be designed as showed in Figure 2.

As Spratt, Humphreys and Chan (2002) reported the case in Hong Kong that students expected their teachers to make all the pedagogical decisions instead of themselves, believing that to teach is the teachers' job. Students who enrol in the university are not always ready for next chapter of life and enjoy autonomy in university. Concluded from teachers' feedback and observation records, the causes are mainly two: (1) education in China's traditional context contains a history of compliance with teachers' 


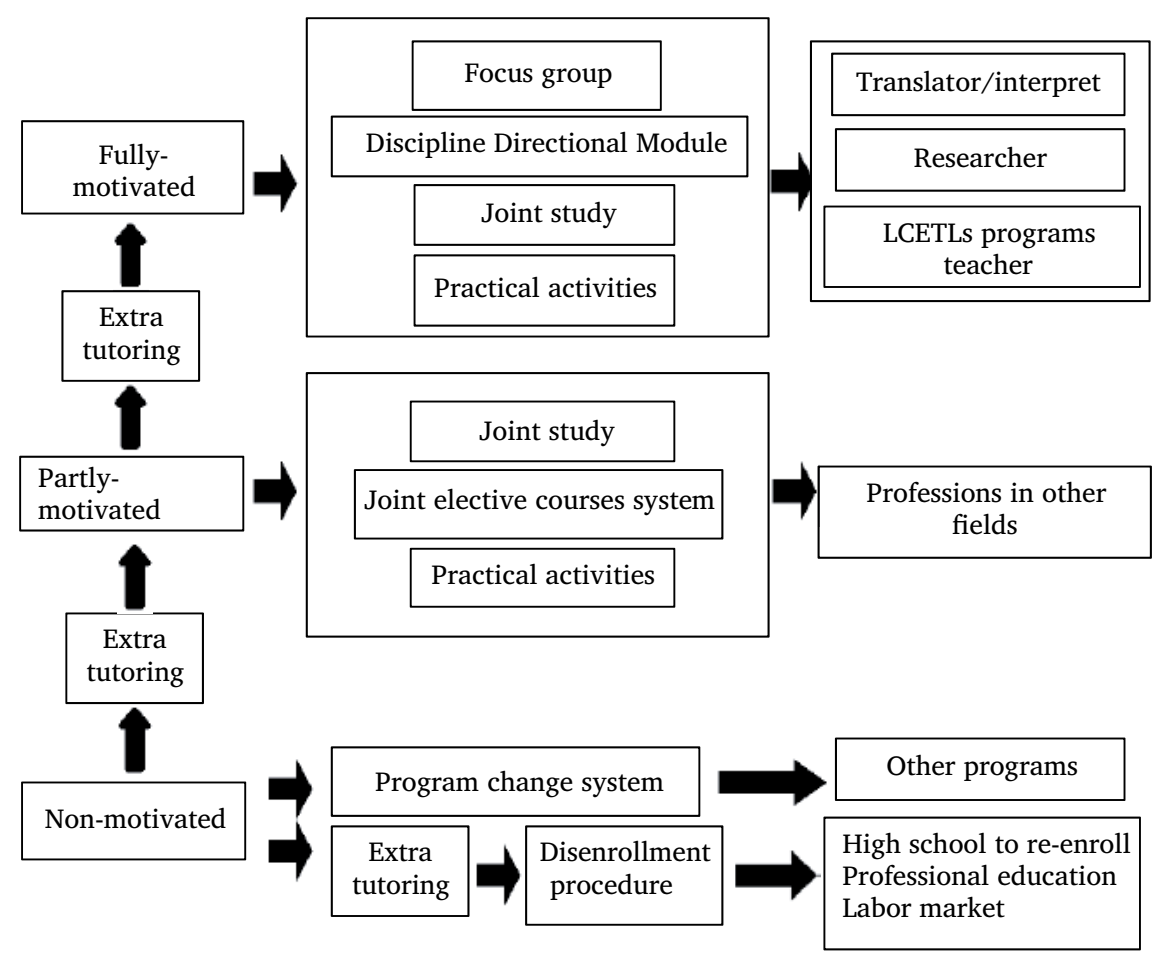

Figure 2. Administrative process in the three motivating situations

instruction; (2) after the National College Entrance Examination, many students feel relaxed from previous pressure and lose the willingness to study as hard as before. For the fully-motivated students, "focus groups" and "Discipline Directional Module" (which guides students to specialise in one social or humanities science sphere with the target language) are designed to deepen their interests and channel them to certain professions, mainly translator/interpreter, researcher and LCTELs teacher/administrator. For the partly-motivated students, while leading them to find their real interest in the "Discipline Directional Module", the curriculum encourages them to join "joint study program", such as LCTELs-Law, LCTELs-Economics programs. Students are encouraged to learn knowledge of another discipline sphere in Chinese or English, while they can succeed in the assessment of LCTEL proficiency. For the non-motivated students, program offers opportunity to be tested for another program in the university during the first academic year. Students, who neither qualify for other programs nor pass assessment in own program after certain amount of extra tutoring hours, will be persuaded to quit and try other possibilities. 


\section{Teachers' needs}

The observation in the teaching process and feedback in the interview show that all the LCTELs programs suffer a shortage of qualified instructors. Generally, the staff structure for one program is 1-3 local teachers and 1 expatriate teacher. LCTELs teachers have very heavy work load: they need to manage and design curriculum, to instruct all courses in different types, to collect and develop teaching materials, to maintain relationship with other stockholders and cooperation with institutions overseas, to care about students and to do research in related fields. Nowadays, in higher educational institutions, one important measurement to teachers is their research capability. And the teachers' continuous level of research will also decide the quality of courses in the "Discipline Directional Module". However, due to inadequate experience and resources, limited time and training programs, this task is much more challenging for LCTELs teachers. A win-win method is to organise research teams guided by specialists, to make interdependence of teaching and research, to collect the hot issues and to assign work according to teachers' individual interest. Therefore, to investigate teachers' research interest, which is also one of teachers' needs, is important for curriculum development. Even in the phase of teachers' recruitment, special attention should be paid to organise research team with teachers of different interest fields.

\section{Institutional needs}

Although many cases on cooperation between the LCTELs programs and the institutions in the target country/region have successfully been implemented, the incompatibility of the different systems and mismatch of needs and supplies remain amount of memorandums on papers. In order to improve the effectiveness of cooperation, the needs analysis of both sides is necessary. From the LCTELs programs' side, the main need is serious courses on language and culture to improve both teachers' and students' language proficiency and culture understanding in the authentic language environment. Scholarship provided to support students in the study by the target country government or educational institutions is also a favourable complementary. From the target country/region side, the needs might be such as: 1) Language and culture promotion abroad; 2) Building of international and intercultural relationships; 3) Increasing international students number leading to raise the place in world university rankings; 4) Exchanging students to study in China, preferably in the program of Chinese language and culture; 5) Sharing the teaching and research resources by exchange of scholars; 6) Gaining profit or financial support; etc. 
In practice, two dilemmas often emerge: 1) the language courses' levels or studying hours offered by the target institutions are not applicable to the students from the LCTELs programs; 2) the faculty which sends students to target country/region and the faculty which is expected to receive students from the target country/region is not the same one. To solve these problems requires further negotiation based on the need analysis.

\section{Component 3: Principles}

Most of the LCTELs instructors are specialised in their chosen language and literature studies, and have little or no background in foreign language teaching methodologies and curriculum design. During the semi-structured interview in July-August, 2017, responses showed that just 4 out of 51 respondents have received systematic training in foreign language acquisition and curriculum design during their master or doctorate studies. The LCTELs instructors have deeper understanding and practical experience in teaching and managing courses, and often follow intuition, not "principles" to make decisions. Practice and theory are disjointed in this situation.

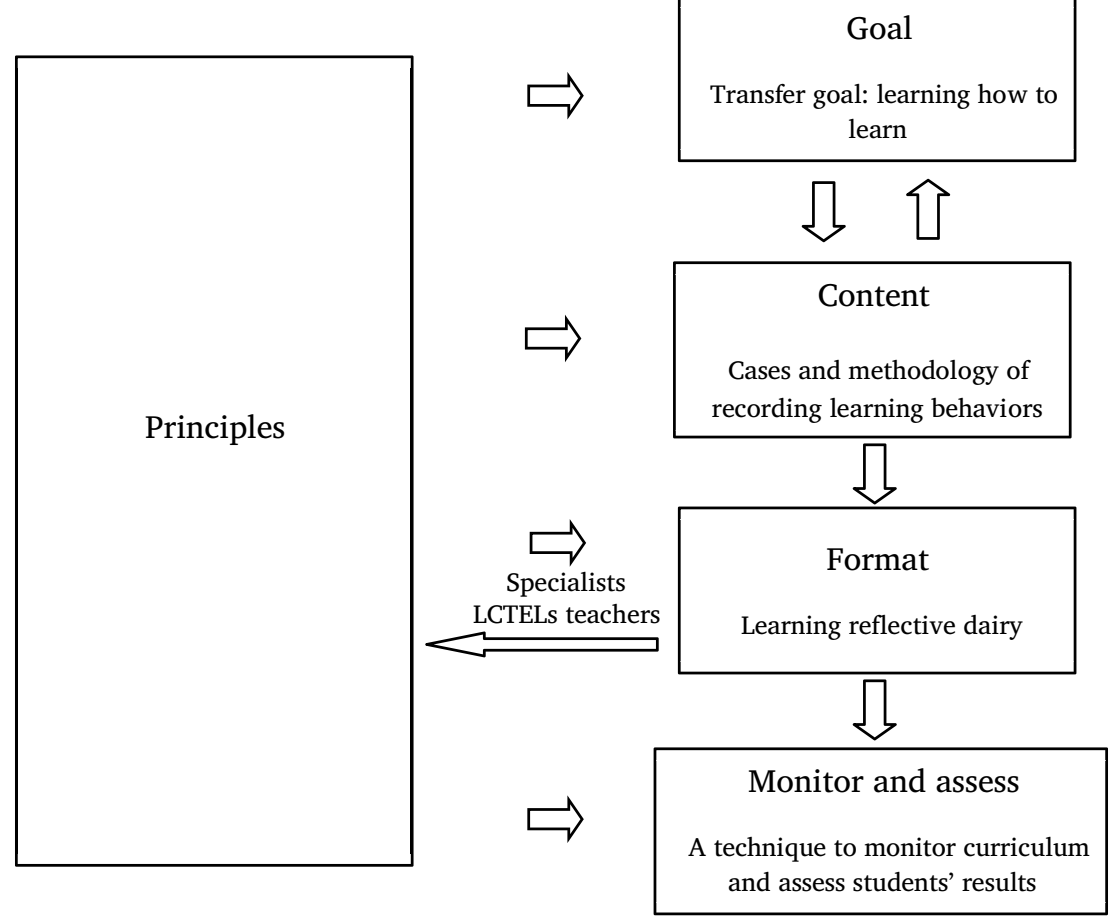

Figure 3. Students' participation in the factor "Principles" 
Increased national attention and the development of LCTLs programs lead researchers in foreign language acquisition and specialists in curriculum design to pay attention more actively to LCTLs. A cooperative mode gradually forms, which consists of such specialists and LCTLs teachers. In joint researches, specialists guide LCTLs teachers to analyse teaching materials with suitable theory and methodology. This mode breaks the boundary between institutions, achieves mutual benefits and gives positive results (Wen, 2016; Wen, Zhang, 2017; Dong, 2016).

Empirical research plays a very important role in investigating teachers' and learners' behaviours to produce "principles". However, it requires long-time and thorough accumulation in daily learning process. Two or three teachers can hardly fulfil such task. Current situation could be turned around with encouragement of students to participate in the active process. It is also a way to connect the factors of curriculum closer. This process can be designed as in Figure 3 .

\section{Component 4: Goals}

Stern (1992) proposed rather comprehensive and applicable classification of goals. He divided goals in the process of language learning into four categories: proficiency goals, cognitive goals, affective goals, and transfer goals. Proficiency goals include general competency, mastery of the four skills (speaking, listening, reading, and writing), or mastery of specific language behaviours. Cognitive goals include mastery of linguistic knowledge and mastery of cultural knowledge. Affective goals include achieving positive attitudes and feelings about the target language, achieving confidence as a user of the language, and achieving confidence in oneself as a learner. Transfer goals involve learning how to learn so that one can call upon learning skills gained in one situation to meet future learning challenges, (Graves, 1996, 17). Good psychological condition and adaptive learning methods are strong support to obtainment of knowledge and skills, thus the last two goals should be emphatically addressed. For students in the LCTELs programs, most of them received good results during their high school period, and their self-expectation is always quite high. LCTELs are relatively unfamiliar and difficult to Chinese learners. When students start new studies in university, they often suffer from uncertainty and stress in competition with other classmates; especially the ones, who had less practice in foreign language communication, in result they easily lose confidence in speaking publicly. When designing curriculum, the communicative approach is applied not only to improve language proficiency, but to achieve positive attitude and to gain techniques for maintaining personal and interpersonal development. 
Language is a tool for communication; however, it is not just a tool. It interrelates with amount of disciplines and offers countless possibilities of future career development. But in one program, it is impossible to exhaust all the possibilities for students. To teach them how to learn and how to plan for their career is more important than the particular skills and knowledge. In order to fulfil the "transfer goals", there is necessary to have, in the curriculum, courses or modules based on general theories and methodologies.

\section{Component 5: Content and sequencing}

One highlight in present LCTELs curriculum is the exchange studies in the target country/region during the $2^{\text {nd }}$ or $3^{\text {rd }}$ academic year. The content of curriculum in this year focuses on improvement of language proficiency and broadening understanding about culture itself. The aim of language proficiency is level B1-B2 in the $2^{\text {nd }}$ academic year or B2-C1 in the $3^{\text {rd }}$ academic year.

However, whether the aim can be achieved or not, mainly depends on the courses provided by the cooperative institutions in the target country/ region. For the Latvian Program, considering the present conditions, if no special fund is offered to customise courses, it is hard to achieve the above-mentioned aim. Currently, in the educational institutions in Latvia, exchange students have opportunity either to attend programs for local students instructed in Latvian, or to join programs for international students mainly instructed in English. If students enter the local students group, the lower language level might make them lag behind; while if they enter the international students group, the academic hours for Latvian language learning are not enough to succeed intended language level. Although in authentic language environment, communicating with local people might be a compensatory method, it is not a systematic way for learning foreign language, especially for adults. Besides, many students are not ready for such autonomous learning. 30 of 134 students in other LCTELs programs, who participated in the questionnaire carried in January, 2017, confirmed that they did not progress much during exchange study, due to their bad management of "free" time.

To revise the "content" or "sequencing" of the curriculum during exchange study can reduce the incompatibility.

\section{Component 6: Evaluation}

Evaluation in Nation \& Macalister's Model specifically refers to assessment of curriculum. Evaluation varies from different levels, mainly including 
national level, university level, faculty level and program level. The first two levels are implemented in a top-down way by curriculum specialists. They are authoritative and executive in the process, and are expected to provide more meaningful instructions for further development. But often in practice, lack of effective feedback system makes the end stay in form. Nowadays, Office Automation System is popularised in educational administration. To publish and share information in such a platform can offer stockholders opportunity to check the evaluation results as they wish. Summative discussion is also necessary to make sure that all staff is well informed.

Evaluation in faculty and program level on the whole is self-check and spontaneous, depending on teachers' schedule. It is often neglected when teachers have heavy workload. However, evaluation in these levels has greater help to teachers either in teaching practice or in research. LCTELs teachers know better the situations in LCTELs teaching. Evaluating each other is an efficient way to find advantages and disadvantages, to achieve self-reflection and to accumulate empirical materials. From faculty administration level, some compulsory measures can be taken to encourage these kinds of evaluation, such as to list it as part of teachers' assessment.

\section{Conclusion}

In recent researches curriculum development was mentioned as essential to enhancing instruction within LCTLs programs. Developing curriculum needs language curriculum development models, which aim at producing relevant, effective and efficient language teaching programs. However, at the present language curriculum development models are mainly rooted in ESL/EFL teaching and learning. Although they give curriculum practitioners good instruction, but still no single model of language curriculum development can claim to have satisfactorily resolved the question of how these criteria are best applied in every case. To achieve a relevant, effective and efficient curriculum development process, on one hand, adoption of the general language curriculum development theory and models are necessary; on the other hand, adaption according to different language teaching and learning features and contexts is also indispensable. Based on the comparison of the existing language curriculum development models, this article adopted Nation \& Macalister's Model as basis, adapted most of the components with considerations in other models and LCTELs teaching practice in China, broadens the discussion to more stockholders involved and explored an expanded model, which is more suitable to the forthcoming enrolment of the Latvian Program either in pedagogic or administrative aspect in China's context, expectedly also to other young LCTELs programs. All considerations in each component still need to be 
examined and revised in further practice, and detailed content of the curriculum will be the further research work.

\section{Acknowledgment}

The research was instructed by Prof. Ilze Kangro and supported by China Scholarship Council.

\section{References}

Brown, A. (2009). LCTL and CTL Students: A Demographic and Academic Comparison. Foreign Language Annals, 42(3), 405-423.

Diffey, N. (1992). Second-language Curriculum Models and Program Design: Recent Trends in North America. Canadian Journal of Education, 17(2), 208-219.

Dong, X. (2016). The Problems of Lesser-Used European Languages Education in China and Some Relevant Advice. Journal of Language Planning, (2), 68-75.

Graves, K. (1996). A Framework of Course Development Processes. In: Graves, K. (Eds.) Teachers as Course Developers (pp. 12-38). Cambridge: Cambridge University Press.

Graves, K. (2000). Designing Language Courses: A Guide for Teachers. Boston: Heinle and Heinle.

Graves, K. (2008). The Language Curriculum: A Social Contextual Perspective. Language Teaching, 41(2), 147-181.

Hutchinson, T., \& Waters, A. (1987). English for Specific Purposes. Cambridge: Cambridge University Press.

Janus, L. (2000). An Overview of Less Commonly Taught Language in the United States. MASSP Bulletin, 84, 25-29.

Johnston, B., \&Janus, L. (2003). Teacher professional development for the less commonly taught languages. Minneapolis, MN: Centre for Advanced Research on Language Acquisition.

Kelly, A. V. (2004). The Curriculum: Theory and Practice. London: SAGE Publications.

Kennedy, C. (1987). Innovating for A Change: Teacher Development and Innovation. ELT Journal, 41(3), 163-169.

Kerr, J. F. (1968). Changing the Curriculum. London: University of London Press.

Lee, Y. A. (2006). Towards Respecification of Communicative Competence: Condition of L2 Instruction or Its Objective. Applied Linguistics, 27(3), 349-376.

Lu, Y. (2018). Investigation of Learning Motivation and Motivating Strategies in Less Commonly Taught European Languages Teaching Context in China. LU Raksti. Izglitibas vadiba, 817, 72-82.

Marsh, C. J. (1997). Perspectives: Key Concepts for Understanding Curriculum. London: The Falmer Press.

Mills, N., Minuchehr, P. (2014). The Development of A National Curriculum Guide for Persian: Themes, Genres, Standards-based Goals, and Models. Journals of NCOLCTL, 16(2), 111-146. 
Murdoch, G. S. (1989). A Pragmatic Basis for Curriculum Design. English Teaching Forum, 27(1), 15-18.

Nation, I. S. P., Macalister, J. (2010). Language Curriculum Design. New York: Routledge.

Nunan, D. (1985). Language Teaching Course Design: Trends and Issues. Adelaide, Australia: National Curriculum Resource Centre.

Nunan, D. (1987). The Teacher as Curriculum Developer. Sydney: National Curriculum Resource Centre, Adult Migrant Education Program.

Richards, J. C. (1985). Language curriculum development. Retrieved from https://scholarspace.manoa.hawaii.edu/bitstream/10125/38633/1/Richards\%20(1985)_WP4(1).pdf

Richards, J. C. (2001). Curriculum Development in Language Teaching. Cambridge: Cambridge University Press.

Richards, J. C. (2013). Curriculum Approaches in Language Teaching: Forward, Central, and Backward Design. RELC Journal, 44(1), 5-33.

Sprrat, M., Humphreys, G., Chan, V. (2002). Autonomy and Motivation: Which Comes First? Language Teaching Research, 6(3), 245-266.

Stern, H. H. (1992). Issues and Options in Language Teaching. Oxford: Oxford University Press.

Tarone, E. (2015). Second Language Acquisition in Applied Linguistics: 1925-2015 and Beyond. Applied Linguistics, 36(4), 444-453.

Wang, S. (2009). Preparing and Supporting Teachers of Less Commonly Taught Languages. Modern Language Journal, 93(2), 282-287.

Wen, Q. (2016). Producing Language-qualified Personnel for "the Belt and Road Initiatives". Chinese Journal of Language Policy and Planning, 2, 20-25.

Wen, Q., Zhang, H. (2017). Career Development of University Teachers of LessCommonly-Taught Foreign Languages: Challenges and Dilemmas, Foreign Languages in China, 6, 96-100.

Yilmaz, F. (2011). Evaluating the Turkish Language Curriculum at Jagiellonian University in Poland: A Case Study. Život i škola, 25(1), 76-90.

Zhong, W. (2015). The Innovative Development of English Majors under the Direction of National Standards of Teaching Quality for Undergraduate English Majors. Foreign Language World, 3, 2-8. 